\title{
Penerapan E-Learning Platform Google Classroom Untuk Menjawab Tantangan Revolusi Industri 4.0
}

\section{(Studi Kasus di Jurusan Akuntansi Politeknik Negeri Padang)}

\author{
Andhita Yolandari' ${ }^{1}$, Reno Fithri Meuthia ${ }^{2}$, Amy Fontanella ${ }^{3}$ \\ 1Jurusan Akuntansi Politeknik Negeri Padang \\ Email :YYolandariandhita@gmail.com \\ 2Jurusan Akuntansi Politeknik Negeri Padang \\ Email : enofm87@gmail.com \\ 3Jurusan Akuntansi Politeknik Negeri Padang \\ Email :amyfontanella99@gmail.com.
}

\begin{abstract}
This research is motivated by a change in the learning system as a result of the 4.0 industrial revolution. This research uses the theory of Technology Acceleration Model (TAM) developed by Fred. D. Davis in 1986. The purpose of this study was to investigate the application of the Google classroom e-learning platform to answer the challenges of the Industrial Revolution 4.0. in Accounting Department in the Polytechnic of Padang. Data gethered using a questionnaire. The population of the study were active students in the Accounting Department of the State Polytechnic of Padang in the 2018/2019 school year with cluster sampling and 241 respondents. The results of this study indicate that perceived usefulness has a positive and significant effect on student interest in using google classroom, and perceived ease of use has a positive and significant effect on student interest in using google classroom. Based on the results of this study indicate several things that must be considered by the Accounting Department of the Padang State Polytechnic before applying the use of technology.
\end{abstract}

Keywords: Industrial revolution 4.0, TAM, E-learning, Google classroom.

\section{ABSTRAK}

Penelitian ini dilatarbelakangi dengan adanya perubahan sistem pembelajaran sebagai akibat dari Revolusi Industri 4.0. Penelitian ini menggunakan teori Technology Accepatance Model (TAM) yang dikembangkan Fred. D. Davis tahun 1986. Tujuan dari penelitian ini adalah untuk mengetahui penerapan e-learning platform google classroom untuk menjawab tantangan revolusi industri 4.0 di jurusan akuntansi politeknik negeri padang. Metode penelitian yang digunakan adalah metode kuantitatif deskriptif dengan menggunakan kuesioner. Populasi dari penelitian adalah mahasiswa aktif di Jurusan Akuntansi Politeknik Negeri Padang pada tahun ajaran 2018/2019 dengan pengambilan sampel secara cluster sampling dan memiliki 241 responden. Hasil dari penelitian ini menunjukkan bahwa perceived usefulness berpengaruh positif dan signifikanterhadap minat mahasiswa menggunakan google classroom, dan perceived ease of use berpengaruh positif dan signifikan terhadap minat mahasiswa menggunakan google classroom. Berdasakan hasil penelitian ini menunjukan beberapa hal yang harus dipertimbangkan oleh Jurusan Akuntansi Politeknik Negeri Padang sebelum menerapkan penggunaan teknologi.

Kata kunci : Revolusi industry 4.0, TAM, E-learning, Google classroom. 
ISSN 2657-1080

ISSN 1858-3687

Akuntansi dan Manajemen Vol.15, No.2, 2020

\section{PENDAHULUAN}

Perkembangan teknologi di era revolusi industry 4.0 dilihat dari seberapa pesatnya perkembangan teknologi informasi dan internet yang digunakan dalam aktivitas sehari-hari. Revolusi industri 4.0 merupakan revolusi industri yang menggabungkan teknologi otomatisasi dengan teknologi cyber. Lee et al (2013) menjelaskan, industri 4.0 ditandai dengan peningkatan digitalisasi manufaktur yang didorong oleh empat faktor: 1) peningkatan volume data, kekuatan komputasi, dan konektivitas; 2) munculnya analisis, kemampuan, dan kecerdasan bisnis; 3) terjadinya bentuk interaksi baru antara manusia dengan mesin; dan 4) perbaikan instruksi transfer digital ke dunia fisik, seperti robotika dan 3D printing. Lifter dan Tschiener (2013) menambahkan, prinsip dasar industri 4.0 adalah penggabungan mesin, alur kerja, dan sistem dengan menerapkan jaringan cerdas di sepanjang rantai dan proses produksi untuk mengendalikan satu sama lain secara mandiri. Era revolusi industri 4.0 mengubah konsep pekerjaan, struktur pekerjaan, dan kompetensi yang dibutuhkan dunia pekerjaan. Sebuah survei perusahaan perekrutan internasional, Robert Walters, bertajuk Salary Survey 2018 menyebutkan, fokus pada transformasi bisnis ke platform digital telah memicu permintaan profesional sumber daya manusia (SDM) yang memiliki kompetensi yang jauh berbeda dari sebelumnya. Era revolusi industri 4.0 juga mengubah cara pandang tentang pendidikan. Perubahan yang dilakukan tidak hanya sekadar cara mengajar, tetapi jauh yang lebih esensial, yakni perubahan cara pandang

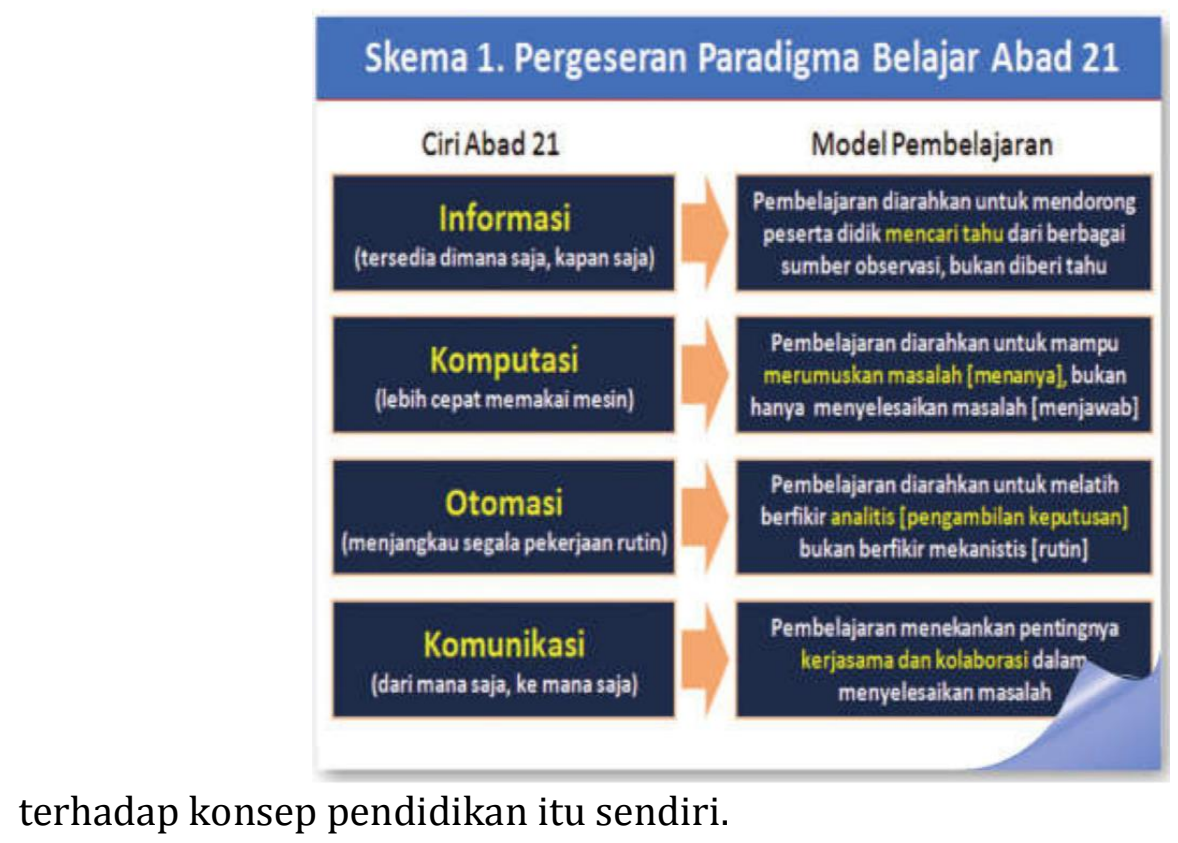

Gambar 1 Pergeseran paradigma belajar abad 21

(Sumber : Sukartono, 2018)

Berdasarkan gambar diatas, syarat penting yang harus dipenuhi untuk bisa menghadapi tantangan pendidikan abad 21 (revolusi industri 4.0) tersebut adalah bagaimana menyiapkan kualifikasi dan kompetensi guru yang berkualitas. 
Salah satu metode pembelajaran yang bisa diterapkan pada masa revolusi industri 4.0 ini adalah metode pembelajaran jarak jauh /e-learning (Sukartono 2018)

E- learning adalah cara modern pembelajaran, yang meliputi media elektronik di bidang pendidikan. Penerapan system e-learning awalnya pada tahun 1960 di University lliinois yang mengembangkan kelas dengan dihubungkan terminal komputer dimana siswa dapat mendengarkan ceramah yan sudah direkam. Pada awal 1960-an beberapa professor dari Stanford University menggunakan komputer untuk mengajar matematika dan membaca di sekolah dasar. Pembelajaran menggunakan komputer inilah yang menjadi cikal bakal perkembangan program e-learning. Dengan adanya perkembangan internet pada tahun 1990-an sekolah korespondensi seperti Phoenix University mulai menunjukkan minat dalam pendidikan virtual. Tahun 1994, CAL Campus SMA online muncul dengan kombinasi pendidikan online dan metode pengajaran tatap muka yang telah lebih sukses dari pada menggunakan 2 metode individual (Agarwal \& Pandey (2013))

Dengan adanya e-learning diharapkan proses pembelajaran yang menyenangkan sehingga menstimulasi mahasiswa untuk mengksplorasi dan mengembangkan potensi kreatif dan inovatifnya, seperti penggunaan klasiber atau website yang dikembangkan oleh UII untuk menunjang proses pembelajaran dimana dosen dapat memberikan tugas kepada mahasiswa pada jam pelajaran kosong dan mahasiswa juga dapat mengumpulkan tugas diluar jadwal pembelajaran dosen tersebut. Salah satu platform e-learning yang user friendly adalah google classroom.

Google Classroom adalah produk dalam $G$-suite untuk pendidikan yang menyertakan google drive, dokumen, spreadsheet, slide, dll. Classroom yang terintegrasi dengan $g$-suite untuk pendidikan bertujuan agar siswa dapat berkomunikasi secara mudah, membuat kelas, mendistribusikan tugas serta tetap terkelola. Menurut penelitian yang dilakukan oleh Izenstark dan Leahy (2015), desain dari Google Classroom sudah tidak asing lagi bagi siswa-siswa karena mereka sudah menggunakan beberapa produk dari Google via akun Google Apps. Siswa-siswa sangat menyukai bagaimana konektivitas antara Google Classroom dengan akun Google Drive .

Salah satu model penggunaan sistem dan teknologi informasi yang dianggap sangat berpengaruh dan digunakan untuk menjelaskan penerimaan individual terhadap sistem dan teknologi informasi tersebut yaitu Technology Acceptance Model (TAM) yang pertama kali diperkenalkan oleh Fred D. Davis pada tahun 1986. Model TAM mempunyai 5 konstruk yang mempengaruhi penggunaan sistem informasi dan teknologi informasi yaitu persepsi kegunaan (perceived usefulness), kemudahan penggunaan (perceived easy of use), sikap terhadap perilaku (attitude toward behaviour), (intention to use), dan perilaku (behaviour). Melihat maraknya penggunaan Google Classroom maka dipandang perlu dilakukan penelitian tentang pengukuran guna memprediksi pengadopsian sistem informasi dan teknologi informasi dengan menggunakan pendekatan TAM. 
Berdasarkan latar belakang diatas, maka penulis ingin melakukan penelitian mengenai "Penerapan E-Learning Platform Google Classroom Untuk Menjawab Tantangan Revolusi Industri 4.0 Di Jurusan Akuntansi Politeknik Negeri Padang"

\section{LANDASAN TEORI}

\section{Technology acceptance model.}

Technology Acceptance Model (TAM) adalah merupakan salah satu model yang dibangun untuk menganalisis dan memahami faktor-faktor yang mempengaruhi diterimanya penggunaan teknologi komputer. Tujuan TAM tidak lain adalah untuk menyediaaakan dasar dalam rangka mengetahui pengaruh dari faktor eksternal terhadap kepercayaan internal, sikap, dan niat. TAM diformulasikan untuk mencapai tujuan ini melalui pengidentifikasian sejumlah kecil variabel pokok, yang didapatkan dari penelitian sebelumnya terhadap teori maupun faktor penentu dari penerimaan teknologi.

TAM diperkenalkan pertama kali oleh Fred Davis pada tahun 1986. Melalui teori ini Davis mengungkapkan bahwa motivasi pengguna sebagai prediktor dalam penggunaan suatu sistem. Model tersebut kemudian dilanjutkan Theory of Reason Action (TRA) oleh Fishben dan Ajzen tahun 1980. Teori TAM mengungkapkan bahwa motivasi pengguna sebagai prediktor dalam penggunaan suatu sistem. Model ini menjelaskan variable-variabel utama dari perilaku pengguna teknologi informasi terhadap penerimaan dan penggunaan teknologi informasi. Variabel yang dimaksud yaitu persepsi kegunaan (perceived usefulness) dan persepsi kemudahan penggunaan (perceived ease of use) (Diksani 2014).

1. Persepsi Manfaat

Perceived Usefulness (persepsi manfaat) merupakan faktor penentu dasar penerimaan pengguna teknologi. Persepsi manfaat yaitu sejauh mana seseorang percaya bahwa menggunakan suatu teknologi akan membantu meningkatkan kinerjanya (Davis, 1989).

2. Perspektif Kemudahan

Perceived Ease of Use (Perspektif kemudahan) penggunaan dapat meyakinkan pengguna bahwasanya teknologi informasi yang akan diaplikasikan adalah suatu hal yang mudah dan bukan merupakan beban bagi mereka. TIK yang tidak sulit digunakan akan terus diaplikasikan oleh perusahaan. Davis (1989) dalam bukunya juga menyatakan bahwa perspektif kemudahan pengaplikasian (perceived ease of use) merupakan sebuah tingkatan dimana seseorang percaya bahwasanya penggunaan sistem tertentu, mampu mengurangi usaha seseorang dalam mengerjakan sesuatu.

Menurut Budhi Rahardjo (2005:2) keamanan informasi adalah bagaimana kita dapat mencegah penipuan (cheating) atau paling tidak, mendeteksi adanya penipuan di sebuah sistem yang berbasis informasi, dimana informasinya sendiri tidak memiliki arti fisik. Menurut Lallmahamood (2007: 7) dalam konteks internet banking, ancaman keamanan adalah serangan atau penyalahgunaan baik 
melalui jaringan transaksi dan transmisi data melalui akses yang tidak sah ke rekening dengan cara otentikasi palsu. Menurut Roger (2003) ada 5 tahap dalam proses penerimaan inovasi teknologi :

1. Tahap pengetahuan.

Dalam tahap ini, seseorang belum memiliki informasi mengenai inovasi baru. Untuk itu informasi mengenai inovasi tersebut harus disampaikan melalui berbagai saluran komunikasi yang ada, bisa melalui media elektronik, media cetak, maupun komunikasi interpersonal diantara masyarakat. Tahapan ini juga dipengaruhi oleh beberapa karakteristik dalam pengambilan keputusan, yaitu: (1) Karakteristik sosial-ekonomi, (2) Nilai-nilai pribadi, dan (3) Pola komunikasi.

2. Tahap persuasi.

Pada tahap ini individu tertarik pada inovasi dan aktif mencari informasi/detail mengenai inovasi. Tahap kedua ini terjadi lebih banyak dalam tingkat pemikiran calon pengguna. Inovasi yang dimaksud berkaitan dengan karakteristik inovasi itu sendiri, seperti: (1) Kelebihan inovasi, (2) Tingkat keserasian, (3) Kompleksitas , (4) Dapat dicoba dan (5) Dapat dilihat.

3. Tahap pengambilan keputusan.

Pada tahap ini individu mengambil konsep inovasi dan menimbang keuntungan/kerugian dari menggunakan inovasi dan memutuskan apakah akan mengadopsi atau menolak inovasi.

4. Tahap implementasi.

Pada tahap ini mempekerjakan individu untuk inovasi yang berbeda-beda tergantung pada situasi. Selama tahap ini individu menentukan kegunaan dari inovasi dan dapat mencari informasi lebih lanjut tentang hal itu.

5. Tahap konfirmasi.

Setelah sebuah keputusan dibuat, seseorang kemudian akan mencari pembenaran atas keputusan mereka. Tidak menutup kemungkinan seseorang kemudian mengubah keputusan yang tadinya menolak jadi menerima inovasi setelah melakukan evaluasi.

\section{E-learning.}

Menurut Michael (2013) adalah sistem pembelajaran yang disusun dengan tujuan untuk menggunakan suatu sistem elektronik atau computer sehingga mampu mendukung suatu proses pembelajaran. Selain itu ardiansyah (2013) berpendapat bahwa e-learning adalah suatu sistem pembelajaran yang digunakan sebagai sebagai sarana pendukung proses belajar mengajar yang dilaksanakan tanpa harus bertatap muka secara langsung antara pendidik dengan siswa/i. Karakteristik dari e-learning menurut Nursalam (2008): 1. Menggunakan bahan ajar bersifat mandiri (self learning material) yang kemudian disimpan didalam komputer, sehingga dapat diakses oleh dosen serta mahasiswa kapanpun dan dimanapun. 2. Memanfaatkan suatu jadwal pembelajaran, kurikulum, hasil kemajuan belajar, serta hal-hal yang berkaitan dengan suatu 
administrasi pendidikan dapat dilihat pada tiap-tiap komputer. 3. Memanfaatkan suatu jasa teknologi elektronik. 4. Memanfaatkan suatu keunggulan komputer (digital media serta juga komputer networks).

Jenis-jenis e-learning berdasarkan teknologi informatika yang digunakan dan dikelompokkan berdasarkan basis teknologi yaitu : (1.) Computer Based Training yaitu sistem e-learning yang mulai berkembang pada tahun 1980-an dan masih terus berkembang sampai saat ini. Sistem ini ditunjang oleh perkembangan sistem animasi yang semakin menarik dan realistis seperti animasi 3 dimensi. (2.) Web Based Training yaitu sistem lanjutan dari sistem CBT dan berbasis teknologi internet. Konsep ini menggunakan model komunikasi 2 arah yang dapat dilakukan oleh para pengguna. Namun, kelancaran pross pembelajaran bergantung kepada infrasstruktur jaringan berkecepatan tinggi. Hal ini menjadi kendala utama untuk penerapan e-learning model web based training karena kecepatan jaringan internet di Indonesia belum merata.

Dalam rangka membedakannya dengan kelas konvensional, sebuah kelas dalam lingkungan belajar berbasis TIK dikenal pula dengan istilah kelas maya (cyber class). Dalam kelas maya, e-learning dimanfaatkan sebagai upaya untuk melengkapi pembelajaran dalam rangka memperkaya materi yang diajarkan dalam kelas konvensional. Model pembelajaran yang menggabungkan antara proses belajar mengajar dalam kelas konvensional dengan kelas maya. Inilah yang kemudian disebut blended learning. Lebih lengkapnya lagi, Josh Bersin (2004) dalam bukunya The Blended Learning Book, menyatakan definisi blended learning adalah kombinasi dari berbagai 'media' belajar (teknologi maupun aktivitas) untuk menciptakan pembelajaran yang optimal bagi siswa. Istilah 'blended' menyatakan bahwa pembelajaran konvensional yang dilaksanakan oleh guru dalam kelas, diperkaya dengan berbagai sumber digital.

\section{Google classroom.}

Google Classroom merupakan aplikasi keluaran Google yang berfungsi mempermudah pekerjaan guru, dosen, dan juga mahasiswa yang memiliki beberapa fasilitas diantaranya mnyediakan bahan ajar, tes yang terintegrasi penilaian, serta mempermudah mahasiswa dalam mengumpulkan tugas meskipun jam kosong dosen atau guru.* Dengan adanya google classroom ini membuat proses pembelajaran menjadi lebih efektif, dan praktis. Selain itu Google Classroom juga memiliki fitur drive yang dapat membantu mahasiswa untuk menyimpan dan menjaga dokumen tugas mahasiswa secara terorganisir. Menurut pengelola g-suite beberapa kelebihan Google Classroom:

a. Dukung Sistem Pembelajaran Paperless. Melalui desain khusus untuk para guru dan siswa, Google Classroom menyediakan serangkaian perangkat gratis penunjang produktivitas Anda, mulai dari Gmail, Drive, dan Docs. Namun, Google Classroom cuma tersedia bagi pengguna Google Apps for Education. Adanya berbagai perangkat tersebut memungkinkan siswa untuk mengerjakan dan mengumpulkan tugas tanpa menggunakan kertas. Nantinya, para guru dapat membuat folder Drive untuk setiap tugas dan untuk siswa sehingga semuanya lebih teratur serta membuat salinan Google Docs secara otomatis untuk setiap siswa/i. 
b. Tak Harus Berada di Ruangan yang Sama. Terdapat fitur yang bernama Class Stream. Fitur ini memungkinkan siswa melakukan debat, diskusi, dan Q\&A (Question \& Ask) dengan sesama siswa lain atau guru. Guru dapat mengirim pertanyaan ke kelas, lalu siswa dan teman-teman bisa berdiskusi untuk menjawab pertanyaan tersebut. Tidak hanya dalam bentuk teks, guru juga bisa mengirim pertanyaan dalam bentuk video atau artikel kemudian meminta siswa untuk menulis rangkumannya. Fitur tersebut memungkinkan siswa dan guru tetap berinteraksi meski tidak berada dalam kelas atau ruang yang sama. Hal ini tentu saja sangat praktis dan hemat waktu bagi guru yang misalnya memiliki kesibukan lain atau siswa yang sedang berada di lokasi yang berbeda.

c. Meningkatkan Hasil Pembelajaran Siswa. Berdasarkan laporan dari OECD (Organisation for Economic Co-operation and Development)* menunjukkan bahwa siswa yang menggunakan komputer dengan intensitas cukup di sekolah cenderung memiliki hasil pembelajaran lebih baik dibandingkan dengan mereka yang jarang menggunakan komputer.

d. Praktis untuk Guru dan Murid. Menggunakan Google Classroom secara langsung dapat memberikan manfaat besar untuk guru dan murid. Seperti contoh, ketika tugas berbentuk pilihan ganda, guru tidak perlu lagi mengoreksi satu persatu di lembaran kertas, dengan Google Classroom nilai akan otomatis keluar saat itu juga. Selain itu juga membantu menganalisa pembahasan mana yang belum dipahami oleh mayoritas murid sehingga pelajaran yang mayoritas belum dipahami tersebut dapat diulangi dengan cara yang lebih baik. Sementara manfaat untuk murid yaitu para murid tetap dapat mengikuti kelas meski murid tersebut berhalangan hadir karena sakit atau tidak memungkinkan datang ke sekolah karena alasan tertentu. Tentu saja cara ini memberikan kesempatan luas bagi murid untuk tetap belajar di mana pun.

e. Bertatap dengan Para Pakar. Google Classroom juga dapat mempertemukan murid dan guru dengan para pakar melalui video call google hangout. Sang pakar tidak perlu hadir di tempat, cukup bertatap secara online melalui video, pembelajaran tetap berjalan lancar.Keberadaan sistem pembelajaran ini memang menarik dan efektif membantu guru atau siswa yang tidak memiliki banyak waktu untuk bertemu tatap muka serta memberikan pengalaman berbeda dari biasanya. 


\section{MODEL PENELITIAN}

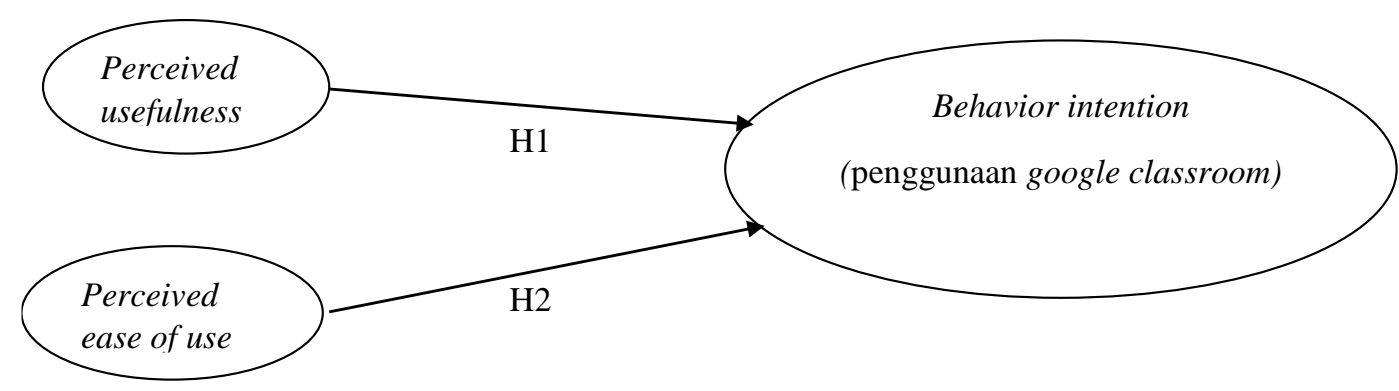

Gambar 2 Model penelitian

(Sumber : Diolah penulis 2019)

\section{Perceived Usefulness (PU).}

Menurut Davis (1989) Perceived usefulness is the degree to which s person believe that using a particular system would enhance his/her job performance. Dalam penelitian Diksani et.al, 2014 jika seseorang merasa percaya bahwa menggunakan sistem berguna maka dia akan menggunakannya. Sebaliknya jika seseorang merasa percaya bahwa sistem informasi kurang berguna maka dia tidak akan menggunakannya. Menurut Syaifuddin (2017) beberapa mahasiswa menganggap e-learning memberikan manfaat dalam proses pembelajaran, serta dapat membantu dalam persiapan kuliah, dengan model blended learning pola mahasiswa dapat mengakses materi sebelum masuk kelas dan mengetahui gambaran aktivitas yang akan dilakukan dengan mempelajari instruksi maupun desain pembelajaran yang tersedia pada e-learning, sehingga materi dapat digunakan untuk belajar secara mandiri dan dosen akan lebih dapat melakukan eksplorasi pembelajaran karena mahasiswa telah memiliki kesiapan terhadap pembelajaran yang akan dilakukan. E-learning membantu mahasiswa untuk mempelajari materi secara mandiri sebelum masuk kelas, dengan mempelajari materi yang disediakan melalui e-learning dapat meningkatkan motivasi mahasiswa dalam proses pembelajaran di dalam kelas. Maka dirumuskan hipotesis sebagai berikut:

\section{H1: Perceived Usefulness berpengaruh terhadap minat mahasiswa untuk menggunakan Google Classroom sebagai media pendukung sistem pembelajaran e-learning}




\section{Perceived Ease Of Use (PEOU).}

Menurut Davis(1989) perceived ease of use is the degree to which a person believe that using a particular system would be free of effort. Menurut Syafuddin (2017) Aksesibilitas merupakan tingkat kenyamanan seseorang untuk mencapai tujuan yang berhubungan dengan perilaku komunikasi. Sebagian besar mahasiswa mengakses e-learning dengan menggunakan web browser baik dari smarthpone maupun laptop, hal ini dikarenakan dalam prosesnya belum dapat diselaraskan dengan android (google playstore). Selain itu, mudah atau tidaknya e-learning diterapkan disebabkan oleh banyaknya mahasiswa yang belum terbiasa dengan sistem e-learning serta minimnya jumlah dosen yang menggunakan metode pembelajaran e-learning. Dalam penelitian Nazar (2008), Persepsi kemudahan penggunaan sebagai tingkat keyakinan seseorang bahwa dalam menggunakan sistem tertentu tidak diperlukan usaha yang keras. Selain itu, persepsi seseorang terhadap e-learning mempengaruhi kemauan dalam menggunakannya atau tidak, dan kemudahan seseorang dalam menggunakan teknologi (e-learning) akan memberikan pengaruh pada sikap pengguna (Aziz, Al Musadieq, \& Susilo, 2013 Oleh karena itu dirumuskan hipotesis sebagai berikut:

\section{H2: Perceived Ease of Use berpengaruh terhadap minat mahasiswa untuk menggunakan Google Classroom sebagai media pendukung sistem pembelajaran e-learning.}

\section{METODE PENELITIAN}

\section{Jenis data}

Jenis data yang digunakan dalam penelitian ini adalah data subyek yaitu jenis data penelitian yang berupa opini, sikap, pengalaman atau karakteristik dari seseorang atau sekelompok orang yang menjadi subyek penelitian (responden).

\section{Sumber data}

Sumber data yang digunakan dalam penelitian ini adalah data primer yaitu penelitian yang diperoleh secara langsung dari sumber asli (tidak melalui perantara). Data primer ini diperoleh dari hasil kuesioner yang dibagikan pada responden, yaitu 244 mahasiswa DIII dan DIV Akuntansi Politeknik Negeri Padang.

\section{Metode analisis data}

Adapun beberapa tahapan dalam penganalisisan data : pertama uji validitas dan reliailitas, uji validitas yaitu teknik pengujian dengan menggunakan 30 responden untuk melihat seberapa besar instrument atau kuesioner yang digunakan dalam peneletian ini memenuhi validitas konstruk. Uji reliabilitas digunakan untuk melihat sejauh mana konsistensi dari instrmen atau kuesioner digunakan dalam penelitian ini. 
Kedua uji asumsi klasik, dalam pengujian ini ada beberapa hal yang dilakukan yaitu uji normalitas, uji heteroskedastisitas, dan uji multikolinearitas. Uji normalitas digunakan untuk melihat apakah data yang digunakan dalam penelitian tersebur berdistribusi normal atau tidak, uji normalitas dalam penelitian ini menggunakan one- sample Kolmogorov smirnov. Uji Heteroskedastisitas yaitu apakah dalam model regresi terjadi ketidaksamaan variansi dari residual satu pengamatan ke pengamatan yang lain. Uji multikolinearitas yaitu pengujian yang bertujuan untuk mengetahui apakah antara variabel bebas dalam penelitian ini terdapat korelasi atau hubungan yang kuat.

Ketiga uji hipotesis, dalam pengujian ini hal-hal yang dilakukan adalah uji koefisien determinasi dan analisis regresi linier berganda. Koefisien determinasi bertujuan untuk melihat seberapa besar variabel bebas atau independent (X) berpengaruh terhadap variabel terikat / dependent (Y). Analisis regresi linier berganda digunakan untuk meramalkan bagaimana keadaan (naik atau turunya) variabel dependen, jika 2 atau lebih variabel independen sebagai prediktor dimanipulasi.

\section{HASIL DAN PEMBAHASAN}

\section{Deskripsi objek penelitian}

Objek penelitian ini adalah mahasiswa di Jurusan Akuntansi Politeknik Negeri Padang. Penelitian ini menggunakan metode purposive sampling dalam menentukan sampel penelitian, sample yang diambil adalah mahasiswa dari Jurusan Akuntansi Politeknik Negeri Padang. Jurusan akuntansi Politeknik Negeri Padang memiliki 2 program studi yaitu prodi diploma 3 dan prodi diploma 4, selain itu dalam penelitian ini dibedakan responden dengan jenis kelamin laki-laki dan jenis kelamin perempuan.

Tabel 1 :Karakteristik Responden

\begin{tabular}{ccc}
\hline Karakteristik & $\begin{array}{c}\text { Frekuensi } \\
\text { (jumlah) }\end{array}$ & Persentase (\%) \\
\hline Program studi : & 128 & 53 \\
Diploma III & 116 & 47 \\
Diploma IV & & \\
Jenis Kelamin : & 50 & 20 \\
Laki-laki & 194 & 80 \\
Perempuan & & \\
\hline
\end{tabular}

Berdasarkan tabel 1 dapat dilihat bahwa berdasarkan kelompok program studi responden mahasiswa program studi Diploma III yaitu sebanyak 128 orang atau sekitar 53\%, dan mahasiswa program studi Diploma IV yaitu sebanyak 116 orang atau sekitar 47\%. Jika dilihat daru jenis kelamin mahasiswa dengan jenis kelamin perempuan yaitu sebanyak 194 orang atau sebesar $80 \%$ dan mahasiswa 
dengan jenis kelamin laki-laki sebanyak 50 orang atau sebanyak 20\%. Hasil pengujian hipotesis penelitian dapat dilihat pada tabel dibawah ini:

Tabel 2

Koefisien determinasi

Model Summary

\begin{tabular}{|c|r|r|r|r|r|}
\hline Model & $\mathrm{R}$ & $\begin{array}{c}\mathrm{R} \\
\text { Square }\end{array}$ & $\begin{array}{c}\text { Adjusted } \\
\mathrm{R} \\
\text { Square }\end{array}$ & $\begin{array}{c}\text { Std. Error of } \\
\text { the Estimate }\end{array}$ & $\begin{array}{c}\text { Durbin- } \\
\text { Watson }\end{array}$ \\
\hline 1 &, $723^{\mathrm{a}}$ &, 523 &, 519 & 2,318 & 1,985 \\
\hline
\end{tabular}

a. Predictors: (Constant), JUMLAH X2, JX1

b. Dependent Variable: JUMLAH Y

(Sumber : output spss versi 20, setelah diolah 2019)

Berdasarkan tabel 2 dapat dilihat bahwa hasil uji regresi linier berganda pada tabel diatas memiliki nilai adjusted $r$ square sebesar 0,519. Hasil pengujian ini menunjukan bahwa 51,9\% minat mahasiswa akuntansi Politeknik Negeri Padang untuk menggunakan google classroom sebagai platform penunjang metode pembelajaran $e$ learning adalah kebermanfaatan dan fasilitas-fasilitas kemudahan yang disediakan oleh teknologi atau aplikasi tersebut. Semakin mudah digunakan serta banyak manfaat yang dirasakan dari penggunaan aplikasi tersebut maka akan semakin besar pula minat mahasiswa untuk menggunakan aplikasi tersebut.

Tabel 3

hasil pengujian hipotesis

\begin{tabular}{|c|c|c|c|c|}
\hline \multicolumn{5}{|c|}{ Y=2,050 + $\mathbf{0 , 0 3 9 9}$ X1 + $\mathbf{0 , 4 3 9}$ X2 + } \\
\hline Variabel & $\begin{array}{c}\text { Prediksi } \\
\text { Arah }\end{array}$ & $\mathrm{B}$ & $\mathrm{T}$ & Sig \\
\hline (constant) & $\mathrm{H} 1:(+)$ & 0,375 & 6,328 & 0 \\
\hline $\begin{array}{c}\text { perceived } \\
\text { usefulness }\end{array}$ \\
$\begin{array}{c}\text { perceived ease of } \\
\text { use }\end{array}$ & $\mathrm{H} 2:(+)$ & 0,419 & 7,084 & 0 \\
\hline
\end{tabular}

(Sumber : output spss versi 20, setelah diolah 2019)

Seperti pada tabel 3 terlihat bahwa pada variable perceveid usefulness memiliki pengaruh positif terhadap variable behavior intention (minat untuk menggunakan). Hal ini dapat dilihat dari nilai signifikansi untuk variable ini yang memiliki nilai 0,00 dimana hal itu lebih kecil dari probalilitas sebesar 0,05. Dimana berarti semakin besar manfaat yang diberikan oleh suatu teknologi, maka akan semakin besar pula minat mahasiswa untuk menggunakan teknologi tersebut. Besarnya manfaat yang dapat dirasakan oleh seseorang tentu didorong oleh seberapa besar pemahamannya terhadap penggunaan teknologi tersebut.

Sama seperti variabel perceived usefulness, variabel perceived ease of use pada penelitian ini juga memiliki pengaruh positif terhadap variabel behavior intention. Besarnya pengaruh ini dilihat dari nilai signifikansi variabel sebesar 0,00 yang lebih kecil dari pada nilai probabilitas 0,05 . Hal ini berarti semakin mudah suatu teknologi digunakan maka akan semakin besar minat dan 
keinginan seseorang untuk menggunakan teknologi tersebut.

Berdasarkan dari kedua variabel diatas berarti dalam memilih sebuah teknologi yang akan digunakan sebagai media pendukung sistem pembelajaran, sebuah lembaga pendidikan harus mempertimbangkan beberapa faktor seperti :

1. Seberapa besar manfaat yang akan di peroleh oleh mahasiswa dan lembaga pendidikan dari penggunaan teknologi tersebut.

2. Seberapa besar fitur yang disediakan oleh teknologi tersebut bisa mempermudah mahasiswa serta dosen dalam mendukung sistem pembelajaran.

3. Serta seberapa mudah teknologi atau aplikasi tersebut dipelajari dan dioperasikan.

Tabel 4 hasil analisis dan pengujian

\begin{tabular}{|c|l|}
\hline HIPOTESIS & \multicolumn{1}{|c|}{ HASIL } \\
\hline Hipotesis 1 & $\begin{array}{l}\text { Variabel perceived usefulness berpengaruh positif terhadap minat } \\
\text { mahasiswa untuk menggunakan google classroom sebagai aplikasi } \\
\text { penunjang sistem belajar e-learning }\end{array}$ \\
\hline Hipotesis 2 & $\begin{array}{l}\text { Perceived Ease of Use berpengaruh positif terhadap minat mahasiswa untuk } \\
\text { menggunakan aplikasi google classroom sebagai media pendukung sistem } \\
\text { pembelajaran e-learning. }\end{array}$ \\
\hline
\end{tabular}

Berdasarkan tabel 3 dan tabel 4, dapat disimpulkan pengaruh dari variabel perceived usefulness dan variabel perceived ease of use seperti dibawah ini :

1. Pengaruh perceived usefulness terhadap minat mahasiswa untuk menggunakan google classroom sebagai media pendukung sistem pembelajaran e-learning.

Berdasarkan hasil analisis regresi linier berganda dapat dilihat bahwa nilai koefsien regresi untuk variabel perceived usefulness berpengaruh positif terhadap minat mahasiswa untuk menggunakan google classroom sebagai aplikasi penunjang sistem belajar e-learning. Dari adanya persepsi ini terlihat bahwa penggunaa google classroom sebagai salah satu aplikasi pendukung metode e-learning merupakan alternatif belajar yang lebih efektif dibandingkan pembelajaran konvensional, dimana pembelajaran dapat berlangsung di luar ruang kuliah selain itu dapat membentuk kemandirian belajar mahasiswa serta membantu mendorong untuk berinteraksi antara mahasiswa satu dengan yang lain. Sejalan dengan penelitian Suardika (2012) yang menemukan bahwa persepsi kegunaan berpengaruh positif dan signifikan terhadap penggunaan teknologi informasi. Namun hasil dari penelitian ini tidak sesuai dengan penelitian dari Santoso (2013) mengatakan bahwa persepsi kegunaan tidak berpengaruh positif dan signifikan terhadap penggunaan teknologi informasi, hal ini dikarenakan semakin lama teknologi tersebut digunakan oleh suatu komunitas maka akan menjadikan hal tersebut biasa bagi pemakai teknologi informasi. Hal ini berarti bahwa minat mahasiswa untuk menggunakan google classroom tergantung pada seberapa besar manfaat yang diperoleh dari penggunaan aplikasi 
tersebut. Sehingga semakin besar manfaat dari sebuah aplikasi semakin besar minat penggunaa untuk menggunakan aplikasi sebagai metode pembelajaran.

2. Pengaruh perceived ease of use terhadap minat mahasiswa untuk menggunakan google classroom sebagai media pendukung sistem pembelajaran e-learning.

Perceived Ease of Use berpengaruh positif terhadap minat mahasiswa untuk menggunakan aplikasi google classroom sebagai media pendukung sistem pembelajaran e-learning. Hasil penelitian ini sejalan dengan penelitian yang dilakukan Suardika (2012) yang menunjukan bahwa persepsi kemudahan berpengaruh positif dan signifikan terhadap penggunaan sistem informasi. Namun hal ini berbanding terbalik dengan penelitian dari Syaefullah (2014) yang menyatakan bahwa persepsi kemudahan tidak berpengaruh positif dan signifikan terhadap penggunaan teknologi informasi dalam hal e-banking. Penelitian yang dilakukan oleh Syaefullah (2014) ini menemukan bahwa faktor kemampuan dibidang teknologi yang menjadi faktor utama sistem informasi bisa dirasakan mudah untuk digunakan. Berdasarkan hasil penelitian ini minat mahasiswa dalam menggunakan aplikasi tergantung kepada seberapa mudah sebuah aplikasi digunakan. Selain itu minat mahasiswa menggunakan google classroom tergantung kepada seberapa efektif dan efisien aplikasi tersebut digunakan.

\section{KESIMPULAN, BATASAN PENELITIAN DAN SARAN}

\section{Kesimpulan.}

Sebagai lembaga pendidikan yang berkewajiban menciptakan sumber daya manusia yang berintelektual serta tanggap akan teknologi, Jurusan Akuntansi Politeknik Negeri Padang mencoba menggunakan google classroom sebuah aplikasi keluaran google yang mencoba mempermudah komunikasi antara dosen dengan mahasiswa. Beberapa faktor yang menjadi penentu apakah teknologi tersebut bisa diterima atau tidak adalah seberapa jauh teknologi tersebut bisa membantu kinerja penggunanya (perceived usefulness) serta sejauh mana teknologi tersebut mampu mengurangi usaha seseorang untuk menyelesaikan pekerjaanya (perceived ease of use).

Berdasarkan hasil pembahasan mengenai perceived usefulness dan perceived ease of use dapat diambil kesimpulan sebagai berikut:

1.Perceived usefulness berpengaruh positif terhadap minat mahasiswa untuk menggunakan google classroom sebagai aplikasi penunjang sistem belajar e-learning.

2. Perceived Usefulness berpengaruh positif terhadap minat mahasiswa untuk menggunakan aplikasi google classroom sebagai media pendukung sistem pembelajaran e-learning. 


\section{Keterbatasan Penelitian.}

Peneliti menyadari bahwa penelitian ini memiliki beberapa keterbatasan. Keterbatasan ini perlu diperhatikan bagi peneliti selanjutnya yang ingin meneliti lebih lanjut maupun oleh pembaca. Keterbatasan yang dimiliki dalam penelitian ini antara lain sebagai berikut:

1. Penelitian ini hanya berfokus variabel persepsi kemudahan dan persepsi kegunaan yang terdapat pada teori Technology Acceptance Model yang dikembangkan oleh Davis.

2. Sampel yang digunakan dalam penelitian ini bersifat homogeny karena hanya melihat persepsi dari mahasiswa jurusan akuntansi di Politeknik Negeri Padang.

\section{Saran.}

Berdasarkan penelitian yang telah dilakukan, peneliti memberikan beberapa saran untuk penelitian selanjutnya sebagai berikut:

1. Penelitian selanjutnya sebaiknya menggunakan variabel-variabel lain yang terdapat dalam teori Unified Theory of Acceptance and Use of Technology (UTAUT) yang dikembangkan oleh Venkatesh (2013), untuk melihat faktor-faktor lainnya yang berpengaruh terhadap minat mahasiswa dalam menggunakan google classroom.

2. Penelitian selanjutnya diharapkan mengambil data dari sampel yang lebih beragam seperti mengambil sampel dari berbagai jurusan yang ada di Politeknik Negeri Padang.

3. Berdasarkan hasil penelitian ini menemukan bahwa sebelum melakukan penerapan metode pembelajaran e-learning jurusan akuntansi Politeknik Negeri Padang sebaiknya mempertimbangkan beberapa hal seperti :

a) Fasilitas jaringan internet dengan kualitas cepat dan memadai

b) Pengetahuan mengenai inovasi tersebut.

\section{REFERENSI}

Agarwal, H., \& Pandey, G. N. (2012) Impact of e-learning in Education. International Journal

Allen, Michael. 2013. Michael Allen's Guide to E-learning. Canada : John Wiley \& Sons.

Ardiansyah, Ivan. 2013. Eksplorasi Pola Komunikasi dalam Diskusi Menggunakan Moddle pada Perkuliahan Simulasi Pembelajaran Kimia. Bandung: Universitas Pendidikan Indonesia. 
Davis, F. D. (1989). Perceived usefulness, perceived ease of use, and user acceptance of information technology. MIS Quarterly, 13(3), 319-340.

Laudon, Kenneth C \& Laudon, Jane P. 2014. Sistem Informasi Manajemen: Mengelola Perusahaan Digital Edisi 13. Jakarta: Penerbit Salemba Empat.

Lee, J., Lapira, E., Bagheri, B., Kao, H., (2013). Recent Advances and Trends in Predictive Manufacturing Systems in Big Data Environment. Manuf. Lett. 1 (1), 38-41.

Liffler, M., \& Tschiesner, A. (2013). The Internet of Things and the Future of Manufacturing. McKinsey \& Company.

Nazar, M. Rafki. 2008. Cognitive Vs Personality Terhadap Niat Pengguna Teknologi (internet). Materi SNA Pontianak, 22-25 Juli 208.

Saifudin, Fuad (2017) E-Learning dalam Persepsi Mahasiswa

Suardikha, Sadha. 2012. Pengaruh Implementasi Budaya Tri Hita Karana Terhadap Penggunaan Sistem Informasi Akuntansi Dimediasi Keyakinan Diri Atas Komputer, Keinovatifan Personal, Persepsi Kegunaan, dan Persepsi Kemudahan Penggunaan Pada Bank Perkreditan Rakyat di Bali (Studi pada Bank Perkreditan Rakyat di Provinsi Bali), Materi SNAXV Universitas Lambung MangkuratBanjarmasin. 20-23 September 2012.

Sukartono. (2018). Revolusi Industri 4.0 dan Dampaknya terhadap Pendidikan di Indonesia 